\title{
Determination of Standards Spectral Oil Sands of the Paraná Basin through Reflectance Spectroscopy Infrared
}

\author{
Lara Ferreira Neves (IC), Prof. Dr. Carlos Roberto de Souza Filho (Guiding), Dra Rosa Pabón \\ (Collaborator)
}

\section{Abstract}

The project aims to spectrally characterize samples of tar-sands of the Paraná Basin through VNIR-SWIR reflectance spectroscopy, in order to determine spectral patterns that can be adapted and used in prospecting for hydrocarbon accumulations in onshore sequences. One of the main products generated in the project was a spectral library comprising the compositional variations of these sandstones.

Key words: Oil Sands, Paraná Basin, Reflectance Spectroscopy.

\section{Introduction}

The tar-sands may contain significant amounts of hydrocarbons (HCs), between $1-18 \%$ of raw bitumen. Sandstones of this nature are found in sequences of the Paraná Basin in various locations (Araujo et al. 2004). The tar-sands can be studied based on reflectance spectroscopy methods using portable spectrometers, covering wavelengths spanning from 350 to $2500 \mathrm{~nm}$. The most important regions for spectral characterization of hydrocarbons considering their diagnostic absorption bands are the NIR and SWIR ranges, more specifically between 1600 and 2400nm (Lammoglia \& Souza Filho, 2011). The study was conducted in the vicinities of Anhembi and Morro do Bofete cities, State of São Paulo, where various architype of tar-sands occur.

\section{Results and Discussion}

The set of samples collected in the field were analyzed in the laboratory aiming at their macroscopic description and determination of their spectral properties. The equipment used for this purpose was the $\mathrm{Hi}$ - Res FieldSpec 4 spectrometer (Analytical Spectral Devices), as well as a contact probe and a reference plate (i.e., Spectralon ) .

For each sample, three to four measurements were made aimed at mapping the maximum possible mineralogical variations and their association with the HCs . For each sample spot, some 50 scans were taken per measurement. Data were processed using the ViewSpecPro software. A spectral library of the samples was generated and interpreted with the aid of tools available in both ENVI and SIMIS software.

\section{Conclusions}

From the analysis of the produced spectral library it was possible to distinguish the mixture of $\mathrm{HC}$ with Illite and Montmorillonite, as well as to semi-quantify their proportions in the samples.

\section{Acknowledgement}

I am grateful to PIBIC-CNPq for the research grant; to Prof. Dr. Carlos Roberto de Souza Filho for the opportunity and supervision of the research, to Dr. Rosa Pabón for her continuous help and to Prof. Dr. Alessandro Batezelli for field support.

\footnotetext{
${ }^{1}$ Araújo, C.C., Yamamoto, J. K., Rostirolla, S.P. (2004).

"Distribuição espacial e caracterização geológica dos arenitos asfálticos da borda leste da bacia do Paraná no estado de São Paulo". RevistaBrasileira de Geociências p.187-198

${ }^{2}$ Lammoglia, $\quad$ T., \& $\quad$ Souza Filho, C. $\quad$ R. Spectroscopic Characterization of oils yielded from Brazilian offshore basins: Potential applications of remote sensing. Remote Sensing Environment, 115, pp. 85-102, 2011.
} 